\title{
YIELD AND QUALITY OF MYCORRHIZED PROCESSING TOMATO UNDER WATER SCARCITY
}

\author{
BAKR, J. ${ }^{1,3^{*}}-$ DAOOD, H. G. ${ }^{2}-$ PÉK, $^{2}{ }^{3}-$ HELYES, L. ${ }^{3}-$ POSTA, K. ${ }^{4}$ \\ ${ }^{1}$ Department of Ornamental Plants, Bakrajo Technical Institute, Sulaimani Polytechnic \\ University, Sulaymaniyah, Kurdistan Region, Iraq \\ ${ }^{2}$ Regional Science Centre, Szent István University, Páter Károly Street 1, Gödöllö H-2100, \\ Hungary \\ ${ }^{3}$ Institute of Horticulture, Szent István University, Páter Károly Street 1, Gödöllö H-2100, \\ Hungary \\ ${ }^{4}$ Plant Protection Institute, Szent István University, Páter Károly Street 1, Gödöllö H-2100, \\ Hungary \\ *Corresponding author \\ e-mail: Jawdat.bakr@gmail.com; phone: +36-20-379-2072 \\ (Received 25 $5^{\text {th }}$ Apr 2016; accepted $13^{\text {th }}$ Oct 2016)
}

\begin{abstract}
An open field trial was established to evaluate production, carotenoids, ascorbic acid, and soluble solids of processing tomato inoculated with arbuscular mycorrhizal fungi either at sowing, and reinoculated at transplanting compared to non-treated plants under different soil moisture conditions. Depending on plant water requirement, all treatments induced to three levels of water supply: Full water supply, half water supply, and no water supply by adjusting the water amount. Regardless of mycorrhizal inoculation time and dosage, plants under no water supply conditions faced severe stress and showed no enhancement in growth, yield, and water use efficiency. Mycorrhizal re-inoculation significantly increased the marketable fruit yield, the total biomass, the water use efficiency, and leaf water potential under water shortage conditions in half water supply compared to at sowing inoculated mycorrhizal plants, and non-treated plants as well, suggesting that field mycorrhizal re-inoculation enhances colonized plant water stress avoidance. A strong negative correlation was observed between yield and soluble solid content. Concisely, mycorrhizal re-inoculation was more effective than inoculation at sowing.
\end{abstract}

Keywords: Solanum lycopersicum M., biofertilizer, carotenoids, water use efficiency, different water regimes

\section{Introduction}

Processing tomato is one of the most important vegetable crops, its production reached 41,374 Mt worldwide, 17,424 Mt in Mediterranean area, and 10,759 Mt in EU (WPTC, 2016). Its high content of carotenes, made tomato an important component in human diet. Humans should take carotenes, since they are ubiquitous organic molecules, which cannot be produces by human body. These group of pigments are accumulate during the ripening process (Helyes et al., 2006; Pék et al., 2010). In Hungary Helyes and coworkers (2002) measured total carotenes in range of 39 to $171 \mathrm{mg} / \mathrm{kg}^{-1}$ in 16 different cultivars of tomatoes. Lycopene and $\beta$-carotene are the most significant compounds belonging to carotenoids. Lycopene forms about $83 \%$ of all carotenoids according to (Lopez et al., 2001), while the later gives $1-3 \%$ of the total carotenoids including the orange tone. $\beta$-carotene is the main source of vitamin A, therefor it is very important for the human health (Francis, 2002). 
In processing tomato high soluble solid content is very important, not only because it results in higher tomato processed into paste, but also needs lower energy cost during the processing (Barrios-Masias and Jackson, 2014). Refractive index is considered the most common tool to estimate the soluble solid content, and its values are reported as percentage or ${ }^{\circ}$ Brix (Johnstone et al., 2005).

Processing tomato consumes large amounts of water (Patanè et al., 2011), thus demanding irrigation throughout the growing season ranging between 400 to $600 \mathrm{~mm}$ depending on climatic conditions (Rana et al., 2000), and this restricts the production in most parts of Europe.

Mycorrhizal fungi are the most vital components within the microbial community, interfacing between the soil and photosynthetic aerial plant parts through their association with plant roots. They are able to form symbiotic relationship with more than $80 \%$ of terrestrial plant families (Smith and Read, 2008) including many land and industrial crops. The mutual symbiosis relationship leads to enhanced plant capability to overcome many abiotic and biotic stressors through enhancing plant nutrient uptake, while in turn the fungus gains plant photosynthates and an ecological niche (Daei et al., 2009; Zhang et al., 2014).

Among the environmental factors, drought stress is considered one of the most fateful abiotic factors that limits agricultural production worldwide (Farooq et al., 2009). Many studies concluded that this symbiosis association protects host plants against the negative impact of drought (Augé, 2001; Smith and Read, 2008; Ruiz-Sánchez et al., 2010). This symbiosis relationship enhances growth and yield in processing tomato (Candido et al., 2015), and may affect tomato quality as well (Ordookhani et al., 2010).

The main mechanisms of arbuscular mycorrhizal symbiosis to alleviate drought stress are the direct and indirect hyphal contribution to the total water uptake which was estimated to be about 20\% (Ruth et al., 2011). According to Endresz et al. (2015), the presence of endogenous arbuscular mycorrhizae fungi (AMF) in the soil can ameliorate the influence of water deficit for resident plant species, but not for new invasive species. Despite the natural presence of AMF in most of the agricultural lands, where members of the Glomeraceae family are dominant (Magurno et al., 2015), field studies illustrated that further inoculation with AMF can enhance both crop productivity and colonization rate (Lekberg and Koide, 2005).

The improvement of stress tolerance is often related to enhanced contents of antioxidant compounds in plants (Hasanuzzaman et al., 2012). Mycorrhized tomatoes increased lycopene and $\beta$-carotene in fruits (Ulrichs et al., 2008); according to Pék and coworkers (2014) abiotic factors such as temperature, light, and water supply affect natural antioxidants composition.

This study is to investigate effects of AMF commercial bio-inoculants on processing tomato UNO ROSSO F1, grown under three different water supplies. Field effectiveness of both inoculation at sowing and re-inoculation during transplantation of mycorrhizae on total biomass, yield, fruit nutritional content, agronomical water use efficiency, and leaf water potential were evaluated.

\section{Materials and Methods}

\section{Experimental conditions}

This experiment was conducted in processing tomato UNO ROSSO F1 (United Genetics Seeds Co. CA, USA) in 2015 on the Institute of Horticulture experimental farm, Szent Istvan University (SIU) in Gödöllö, Hungary $\left(47^{\circ} 59^{\prime} \mathrm{N}, 19^{\circ} 35^{\prime} \mathrm{E}\right)$. The experimental soil was brown forest soil, sandy loam in texture consists of $69 \%$ sand, $22 \%$ silt, and $9 \%$ clay, 
$1.57 \mathrm{~g} \mathrm{~cm}^{-3}$ bulk density, $19 \%$ field capacity, neutral in $\mathrm{pH}$, free from salinity $\left(0.16 \mathrm{dS} \mathrm{m}^{-1}\right)$ and low in organic carbon, $\mathrm{NO}_{3}^{-}-\mathrm{N}\left(5 \mathrm{~g} \mathrm{~kg}^{-1}\right), \mathrm{P}_{2} \mathrm{O}_{2}\left(15 \mathrm{~g} \mathrm{~kg}^{-1}\right), \mathrm{K}_{2} \mathrm{O}\left(35 \mathrm{~g} \mathrm{~kg}^{-1}\right)$; the water table was below $5 \mathrm{~m}$, which could not influence the water turnover.

Tomato seedlings have been propagated on $13^{\text {th }}$ of April in a greenhouse using special horticulture substrate (Klasmann TS3) and inoculated with mycorrhizae (AM+) or not (Control). The mycorrhizal fungi corresponding to a commercial product Symbivit ${ }^{\circledR}$ (mixture of G. mosseae, G. etunicatum, G. claroideum, G. microaggregatum, G. geosporum, and $R$. irregularis) produced by Symbiom Ltd. (Czech Republic, www.symbiom.cz) was applied at a dosage of $25 \mathrm{~g} / \mathrm{L}^{-1}$ substrate. After 4 weeks of growth the AM+ and Control- seedlings were bedded out on $11^{\text {th }}$ of May. During transplantation to the field one-half of the inoculated seedlings were re-inoculated $(\mathrm{AM}++)$ by adding $\left(20 \mathrm{~g} /\right.$ plant $\left.^{-1}\right)$ of Symbivit inoculum into the planting hole and seedlings were planted immediately.

The experimental design was randomized block with four replications per treatment. Seedlings were arranged in double (twin) rows with $1.2 \mathrm{~m}$ and $0.4 \mathrm{~m}$ inter rows distance and $0.2 \mathrm{~m}$ between plants. Three watering regimes: Full water supply (WS $\mathrm{W}_{100}$ ), half water supply $\left(\mathrm{WS}_{50}\right)$, and no water supply $\left(\mathrm{WS}_{0}\right)$, were implemented through a drip irrigation system. Water amount was controlled according Pék et al. (2014) depending on air temperature (daily water demand $=$ daily average temperature $\mathrm{x} 0.2$ ). Weather forecasts from the National Metrological institute were used to calculate the plants daily water demand depending on the daily average air temperature and precipitation. Plant nutrition requirements and plant protection were regulated according to Helyes and Varga (1994) throughout the growing season. Fruits and total biomass were harvested within two weeks first the $\mathrm{WS}_{0}$ tomatoes on $11^{\text {th }}$ of August, followed by both $\mathrm{WS}_{50}$, and $\mathrm{WS}_{100}$ tomatoes on $25^{\text {th }}$ of August.

\section{Soil water content assessment}

Volumetric soil water content was taken by digital soil moisture meter PT1 (Kapacitiv Kkt., Budapest, Hungary) at six different soil depths (5, 10, 15, 20, 25, and $30 \mathrm{~cm})$ just prior to watering.

\section{Root colonization estimation}

Samples for estimating root colonization five plants were dug out (with a soil core of $25 \times 25 \times 25 \mathrm{~cm}$ ) randomly chosen from the repetitive plots of the same treatment. A representative subsample of the roots regarding different treatments was cut to $10 \mathrm{~mm}$ pieces and five randomly selected pieces from each sample were subjected to Trypan Blue staining (Phillips and Hayman, 1970). Internal fungal structures (hyphae, arbuscules) were examined under a stereomicroscope at $\times 100$ magnification and the percentage of root length colonized was calculated using the gridline intersect method (Giovannetti and Mosse, 1980). Mycorrhizal colonization was measured only at harvesting therefore the interpretation of colonization level should be put on more guard. Moreover the applied staining method was not able to make differences between active and non-active mycorrhizal part.

\section{Water use efficiency and mycorrhizal dependency calculation}

Water use efficiency (WUE) was calculated depending on total fresh biomass (WUE $=\mathrm{kg}$ biomass per hectare $/ \mathrm{m}^{-3}$ water consumed per hectare), and mycorrhizal 
dependency (MD \%) was estimated after Planchette et al. (1983) depending on marketable yield by $[\mathrm{MD} \%=$ marketable yield $(\mathrm{AM}+)-$ marketable yield (Control)/ marketable yield $(\mathrm{AM}+)]$.

\section{Leaf water potential measurement}

Pressure bomb (PMS Instruments Co., Corvallis, OR, USA) was used to determine leaf water potential ( $\psi_{\text {leaf }}$ ) at midday by cutting a newly mature leaf from each plant, four replication per treatment and for three consecutive weeks.

\section{Analysis of carotenoid components and vitamin C}

\section{Extraction of carotenoids and ascorbic acid}

Carotenoids extraction was done according to the method of Daood et al. (2014). Five grams of well homogenized tomato has been taken in triplicate followed by disintegrated in a crucible mortar in the presence of quartz sand. The water was then removed by adding $25 \mathrm{ml}$ of methanol along with the repeat disintegration of the aggregating bulk. After the addition of $70 \mathrm{ml}$ of a $6: 1$ dichloroethanemethanol solution, the mixture was transferred quantitatively into $100 \mathrm{ml}$ conical flask. Moreover, the mixture was shaken up to 15 min by mechanical shaker. Few drops of double distilled water were added to separate the two phases. The pigment containing lower layer was separated in a separating funnel, dried over anhydrous sodium sulphate and passed into a round-bottom flask. The organic solvent was evaporated with vacuum by rotary evaporator (IKA ${ }^{\circledR}$ RV10, Sigma-Aldrich Ltd., Budapest, Hungary) at maximum $40{ }^{\circ} \mathrm{C}$ and the residues were re-dissolved in $5 \mathrm{ml}$ of HPLC grade acetone.

Ascorbic acid was extracted from 5 grams of well homogenized tomato by crushing in a crucible mortar and shaking for 15 min with $3 \%$ metaphosphoric acid solution. The mixture was then filtered through a filter paper and purified by a 45 um nylon syringe filter before injection on to the HPLC column.

\section{HPLC equipment and conditions}

A Chromaster liquid chromatograph in (Hitachi, japan) consisting of a Model 5110 Gradient pump, a Model 5210 auto sampler and a Model 5430 photodiode array detector was used. Operation and data processing were performed by EZChroma Elite software.

The separation of carotenoids was done on cross-linked C-18, $3 \mu \mathrm{m}, 150 \times 4.6 \mathrm{~mm}$ column using gradient elution of water in acetone as described by Daood et al. (2014). The column effluents were detected at their maximum absorption wavelength for identification and quantification. The retention properties and spectral characteristics of the detected peaks were compared with some available standard materials like lycopene, $\beta$-carotene and zeaxanthin (Sigma-Aldrich Ltd., Budapest, Hungary). In case of absence of standards, the tentative identification was done based on comparison of retention times and spectral characteristics with literature data. Additionally, the compounds were quantified as either lycopene- or $\beta$ - carotene-equivalent based on their spectral characteristics.

As for ascorbic acid, separation was performed on C-18, $240 \times 4.6 \mathrm{~mm}$, 5um column under ion-pair chromatographic conditions optimized and validated by Daood et al., 
(1994). Ascorbic acid was identified using standard material (Sigma-Alrrich, Budapest), from which stock and working solutions were prepared for getting the calibration curve.

\section{Brix determination}

Digital Refractometer Krüss DR201-95 (Küss Optronic, Hamburg, Germany) was used to estimate the ${ }^{\circ}$ Brix.

\section{Statistical analysis}

Statistical analyses were performed using the software IBM SPSS Statistics for Windows, Version 22.0. (IBM Hungary, Budapest, Hungary). Analysis of variances was done by two way ANOVA to separate the mycorrhizal effect, water supply effect, and their interaction. Tukey's tests were performed for every possible pairwise comparison.

\section{Results}

Precipitation occasions and their amounts were relatively well distributed during the first two months of the growing period, and plants received the first rain directly after the transplantation, thus the first watering was started in the first week of June.

Irrigation supply resulted in $426.3 \mathrm{~mm}$ and $306.3 \mathrm{~mm}$ totally for both $\mathrm{WS}_{100^{-}}$and $\mathrm{WS}_{50}$-regimes respectively including $186.3 \mathrm{~mm}$ of rain, while $\mathrm{WS}_{0}$ plants received only $186.3 \mathrm{~mm}$ of rainfall (Fig. 1). Volumetric soil water contents was ranging between 0.14$0.17,0.11-0.14$, and $0.07-0.10$ during the growing season, corresponding to $73-89 \%$, $58-73 \%$, and $37-52 \%$ of field capacity in $\mathrm{WS}_{100}, \mathrm{WS}_{50}$, and $\mathrm{WS}_{0}$ blocks respectively.

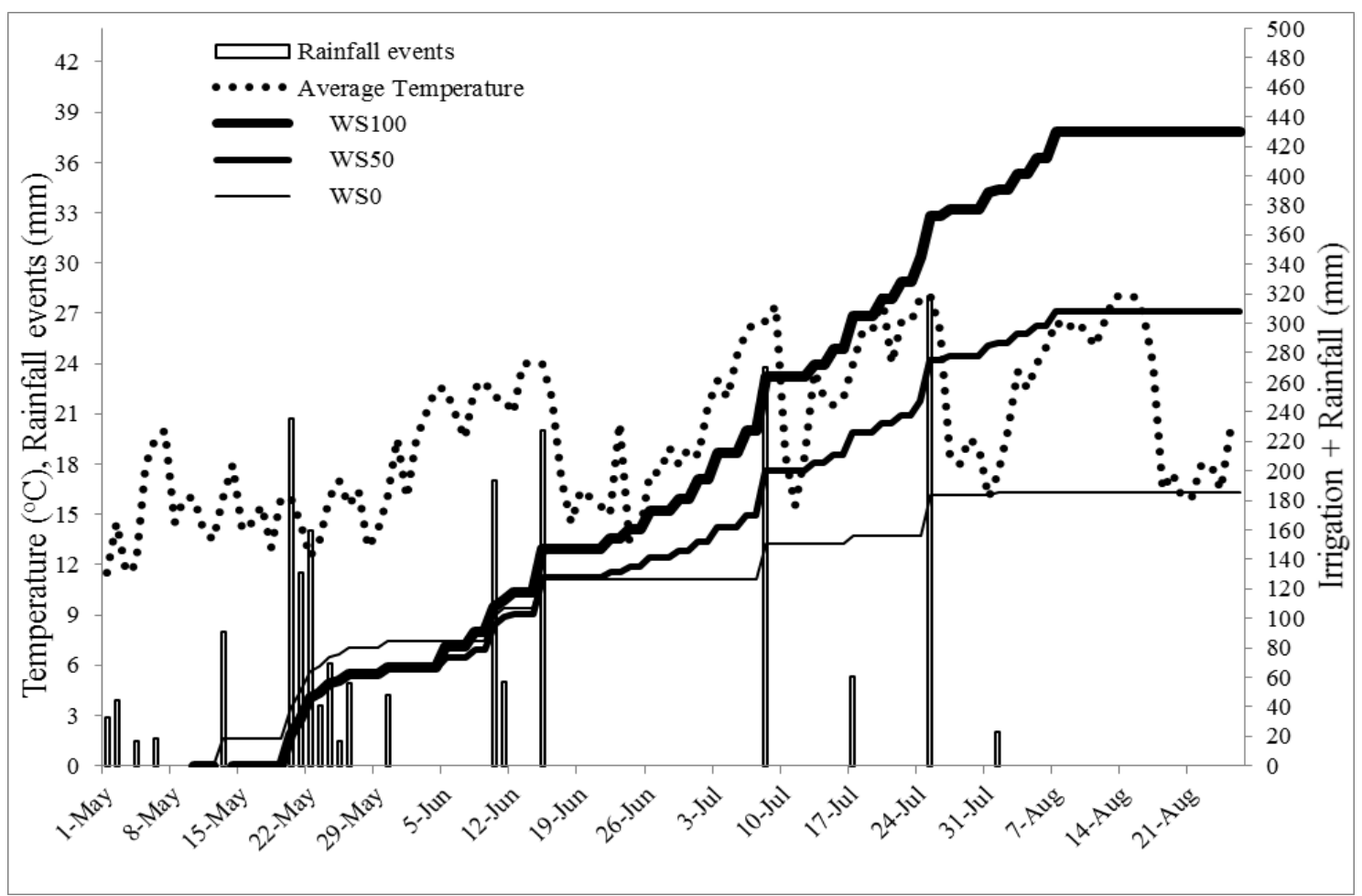

Figure 1. Average daily temperature, precipitation, and accumulative irrigation amount in 2015. 
The last 3 weeks of no rain caused severe stress to all mycorrhized and noninoculated plants in unirrigated $\mathrm{WS}_{0}$ treatments (Fig. 1), therefore no enhancements in total biomass and water use efficiency were observed due to mycorrhizal inoculation, although root colonization rates in both $\mathrm{AM}+$ and $\mathrm{AM}++$ significantly increased (Table 1). AM++ plants improved the total biomass and WUE by $73 \%$ and $42 \%$ compared to Control and $\mathrm{AM}+$ plants under $\mathrm{WS}_{50}$, while mycorrhizal effect lessened under full water supply $\mathrm{WS}_{100}$. The same trend was also observed in mycorrhizal dependency MD \%, which was pronounced clearly in AM++ treatment especially under half water supply $\mathrm{WS}_{50}$ regime (Table 1).

Table 1. Water Use Efficiency (WUE), Mycorrhizal Dependency (MD \%). Means with same letters are not significantly different at $(P<0.05)$ as determined by Tukey's HSD test (Mean \pm $S D, n=4)$. Capital letters represent mycorrhizal inoculation effect, small letters represent water supply effect.

\begin{tabular}{|c|c|c|c|c|c|}
\hline Water Supply & Treatments & Total Biomass $\mathrm{t} \mathrm{ha}^{-1}$ & WUE $\mathrm{kg} \mathrm{m}^{-3}$ & Root Colonization \% & $\mathrm{MD} \%$ \\
\hline \multirow{3}{*}{$\begin{array}{c}\text { No } \\
\text { water supply }\end{array}$} & Control & $33.5^{\mathrm{Aa}} \pm 2.2$ & $18.0^{\mathrm{Aa}} \pm 2.4$ & $54^{\mathrm{Aa}} \pm 6$ & \\
\hline & $\mathrm{AM}+$ & $32.6^{\mathrm{Aa}} \pm 0.4$ & $17.5^{\mathrm{Aa}} \pm 0.4$ & $67^{\mathrm{Ba}} \pm 8$ & 3.14 \\
\hline & AM++ & $34.6^{\mathrm{Aa}} \pm 1.4$ & $18.6^{\mathrm{Aa}} \pm 0.4$ & $70^{\mathrm{Ba}} \pm 6$ & 1.57 \\
\hline \multirow{3}{*}{$\begin{array}{c}\text { Half } \\
\text { water supply }\end{array}$} & Control & $74.3^{\mathrm{Ab}} \pm 1.4$ & $24.3^{\mathrm{Ab}} \pm 0.9$ & $49^{\mathrm{Aa}} \pm 6$ & \\
\hline & $\mathrm{AM}+$ & $91.2^{\mathrm{Bb}} \pm 1.8$ & $29.8^{\mathrm{Bc}} \pm 1.2$ & $64^{\mathrm{Ba}} \pm 9$ & 11.66 \\
\hline & $\mathrm{AM}++$ & $128.9^{\mathrm{Cc}} \pm 1.5$ & $42.1^{\mathrm{Cc}} \pm 1.0$ & $63^{\mathrm{Ba}} \pm 8$ & 41.49 \\
\hline \multirow{3}{*}{$\begin{array}{c}\text { Full } \\
\text { water supply }\end{array}$} & Control & $92.6^{\mathrm{Bc}} \pm 1.2$ & $21.7^{\mathrm{Bc}} \pm 0.6$ & $55^{\mathrm{Aa}} \pm 6$ & \\
\hline & $\mathrm{AM}+$ & $74.3^{\mathrm{Ac}} \pm 1.5$ & $17.4^{\mathrm{Ab}} \pm 0.7$ & $73^{\mathrm{Ba}} \pm 6$ & -18.68 \\
\hline & $\mathrm{AM}++$ & $100.0^{\mathrm{Cb}} \pm 2.6$ & $23.5^{\mathrm{Cb}} \pm 1.2$ & $71^{\mathrm{Ba}} \pm 6$ & 9.24 \\
\hline \multicolumn{2}{|c|}{ Significant of Source of variation } & \multicolumn{4}{|c|}{$(\mathrm{ns}=$ not significant, $* \mathrm{P} \leq 0.05, * * \mathrm{P} \leq 0.01, * * * \mathrm{P} \leq 0.001)$} \\
\hline \multicolumn{2}{|c|}{ Mycorrhizae (M) } & **** & **** & $* * *$ & \\
\hline \multicolumn{2}{|c|}{ Water Supply (WS) } & **** & **** & ns & \\
\hline \multicolumn{2}{|c|}{$\mathrm{M} * \mathrm{WS}$} & **** & **** & ns & \\
\hline
\end{tabular}

Re-inoculated plants $(\mathrm{AM}++)$ at transplantation gave higher yield compared to those inoculated at sowing $(\mathrm{AM}+)$ or non-inoculated (Control) . AM++ plants under $\mathrm{WS}_{50}$ level gave the highest marketable yield reaching $96.47 \mathrm{t} \mathrm{ha}^{-1}$ exceeding both control and AM+ treatments by $71 \%$ and $51 \%$ respectively, while mycorrhization effect was slowed down under $\mathrm{WS}_{100}$ regime and AM++ plant gave higher marketable fruits only by $10 \%$ and $31 \%$ compared to control and $\mathrm{AM}+$ plants with no remarkable differences in $\mathrm{WS}_{0}$ (Table 2).

Table 2. Fruit and antioxidant production per unit area. Means with same letters are not significantly different at $(P<0.05)$ as determined by Tukey's HSD test (Mean $\pm S D, n=4)$. Capital letters represent mycorrhizal inoculation effect, small letters represent water supply effect.

\begin{tabular}{|c|c|c|c|c|c|c|}
\hline Water Supply & Treatments & $\underset{\mathrm{t} \mathrm{ha}^{-1}}{\text { Marketable }}$ & $\begin{array}{c}\text { Total Carotene } \\
\mathrm{kg} \mathrm{ha}^{-1}\end{array}$ & $\begin{array}{l}\text { Lycopene } \\
\mathrm{kg} \mathrm{ha}^{-1}\end{array}$ & $\begin{array}{c}\beta \text {-Carotene } \\
\mathrm{g} \mathrm{ha}^{-1}\end{array}$ & \begin{tabular}{|c|} 
Ascorbic Acid \\
$\mathrm{kg} \mathrm{ha}^{-1}$
\end{tabular} \\
\hline \multirow{3}{*}{$\begin{array}{c}\text { No } \\
\text { water supply }\end{array}$} & Control & $14.69^{\mathrm{Aa}} \pm 2.6$ & $2.00^{\mathrm{Ba}} \pm 0.3$ & $1.47^{\mathrm{Ba}} \pm 0.24$ & $38.5^{\mathrm{Ba}} \pm 6.5$ & $4.90^{\mathrm{Aa}} \pm 1.3$ \\
\hline & $\overline{\mathrm{AM}+}$ & $15.16^{\mathrm{Aa}}$ & $1.15^{\mathrm{Aa}} \pm$ & $0.87^{\mathrm{Aa}} \pm 0.08$ & $22.2^{\mathrm{Aa}} \pm 3.5$ & $4.73^{\mathrm{Aa}} \pm 0.8$ \\
\hline & $\overline{\mathrm{AM}++}$ & $14.92^{\mathrm{Aa}} \pm 2.0$ & $2.18^{\mathrm{Ba}} \pm 0.3$ & $1.68^{\mathrm{Ba}} \pm 0.22$ & $48.7^{\mathrm{Ba}} \pm 9.9$ & $5.41^{\mathrm{Aa}} \pm 0.9$ \\
\hline \multirow{3}{*}{$\begin{array}{c}\text { Half } \\
\text { water supply }\end{array}$} & Control & $56.45^{\mathrm{Ab}} \pm 2.3$ & $6.01^{\mathrm{Ab}} \pm 0.7$ & $4.07^{\mathrm{Ab}} \pm 0.49$ & $126.0^{\mathrm{Ab}} \pm 25$ & $16.1^{\mathrm{Ab}} \pm 1.6$ \\
\hline & & $63.91^{\mathrm{Ab}} \pm 6.1$ & $7.64^{\mathrm{Ac}} \pm 1.4$ & $5.84^{\mathrm{Bc}} \pm 1.14$ & $161.2^{\mathrm{Ab}} \pm 31$ & $18.5^{\mathrm{Ab}} \pm 2.4$ \\
\hline & $\mathrm{AM}++$ & $96.47^{\mathrm{Bc}} \pm 6.0$ & $8.71^{\mathrm{Bc}} \pm 0.6$ & $6.48^{\mathrm{Bc}} \pm 0.50$ & $182.2^{\mathrm{Bb}} \pm 19$ & $29.4^{\mathrm{Bc}} \pm 1.9$ \\
\hline
\end{tabular}




\begin{tabular}{|c|c|c|c|c|c|c|}
\hline \multirow{3}{*}{$\begin{array}{c}\text { Full } \\
\text { water supply }\end{array}$} & Control & $68.41^{\mathrm{Bc}} \pm 3.7$ & $6.46^{\mathrm{Ab}} \pm 1.4$ & $4.53^{\mathrm{Ab}} \pm 0.62$ & $165.3^{\mathrm{Ab}} \pm 28$ & $18.7^{\mathrm{Ab}} \pm 1.6$ \\
\hline & AM+ & $57.64^{\mathrm{Ab}} \pm$ & $5.40^{\mathrm{Ab}} \pm 0.8$ & $3.89^{\mathrm{Ab}} \pm 0.40$ & $172.3^{\mathrm{Ab}} \pm 28$ & $16.7^{\mathrm{Ab}} \pm 1.9$ \\
\hline & $\mathrm{AM}++$ & $75.38^{\mathrm{Bb}} \pm 3.4$ & $6.05^{\mathrm{Ab}} \pm 0.4$ & $3.70^{\mathrm{Ab}} \pm 0.24$ & $223.0^{\mathrm{Ab}} \pm 52$ & $20.5^{\mathrm{Bb}} \pm 1.5$ \\
\hline \multicolumn{7}{|c|}{ Significant of Source of variation $\quad(\mathrm{ns}=$} \\
\hline \multicolumn{2}{|c|}{ Mycorrhizae (M) } & $* * *$ & $*$ & $*$ & $* *$ & $*:$ \\
\hline \multicolumn{2}{|c|}{ Water Supply (WS) } & $* * *$ & $* * *$ & $* * *$ & $* * *$ & $* * *$ \\
\hline \multicolumn{2}{|c|}{$\mathrm{M} * \mathrm{WS}$} & $* * *$ & $* *$ & $* * *$ & ns & $* * *$ \\
\hline
\end{tabular}

Re-inoculated plants $(\mathrm{AM}++)$ gave not only the highest yield under $\mathrm{WS}_{50}$, but also accumulated higher ascorbic acid, while irrigation influenced negatively the carotenoids concentration (Table 3), but higher yield overcame the concentration loss by higher production of antioxidants per unit area (Table 2).

Table 3. Antioxidants concentrations $\left(\mathrm{mg} \mathrm{kg}^{-1}\right)$. Means with same letters are not significantly different at $(P<0.05)$ as determined by Tukey's HSD test (Mean $\pm S D, n=4)$. Capital letters represent mycorrhizal inoculstion effect, small letters represent water supply effect.

\begin{tabular}{|c|c|c|c|c|c|}
\hline Water Supply & Treatments & Total Carotene & Lycopene & $\beta$-Carotene & Ascorbic Acid \\
\hline \multirow{3}{*}{$\begin{array}{c}\text { No } \\
\text { water supply }\end{array}$} & Control & $136.3^{\mathrm{Bb}} \pm 1.3$ & $100.1^{\mathrm{Bb}} \pm 2$ & $2.63^{\mathrm{Ba}} \pm .22$ & $330^{\mathrm{Ab}} \pm 30$ \\
\hline & AM+ & $76.01^{\mathrm{Aa}} \pm 5.2$ & $57.4^{\mathrm{Aa}} \pm 5$ & $1.46^{\mathrm{Aa}} \pm .14$ & $311^{\mathrm{Aa}} \pm 32$ \\
\hline & AM++ & $146.5^{\mathrm{Bb}} \pm 15$ & $113.4^{\mathrm{Bc}} \pm 12$ & $3.24^{\mathrm{Cb}} \pm .36$ & $361^{\mathrm{Ab}} \pm 12$ \\
\hline \multirow{3}{*}{$\begin{array}{c}\text { Half } \\
\text { water supply }\end{array}$} & Control & $106.3^{\mathrm{Ba}} \pm 7.7$ & $72.0^{\mathrm{Ba}} \pm 6$ & $2.23^{\mathrm{Aa}} \pm .42$ & $286^{\mathrm{Aa}} \pm 26$ \\
\hline & $\mathrm{AM}+$ & $119.5^{\mathrm{Bb}} \pm 19$ & $91.3^{\mathrm{Bb}} \pm 15$ & $2.50^{\mathrm{Bb}} \pm .26$ & $293^{\mathrm{Aa}} \pm 58$ \\
\hline & $\mathrm{AM}++$ & $90.75^{\mathrm{Aa}} \pm 11$ & $67.5^{\mathrm{Ab}} \pm 9$ & $1.89^{\mathrm{Aa}} \pm .88$ & $304^{\mathrm{Aa}} \pm 07$ \\
\hline \multirow{3}{*}{$\begin{array}{c}\text { Full } \\
\text { water supply }\end{array}$} & Control & $94.27^{\mathrm{Aa}} \pm 19$ & $66.1^{\mathrm{Ba}} \pm 7$ & $2.42^{\mathrm{Aa}} \pm .30$ & $273^{\mathrm{Aa}} \pm 14$ \\
\hline & $\mathrm{AM+}$ & $93.83^{\mathrm{Aa}} \pm 6.3$ & $67.7^{\mathrm{Ba}} \pm 7$ & $2.32^{\mathrm{Ab}} \pm .50$ & $289^{\mathrm{Aa}} \pm 10$ \\
\hline & $\mathrm{AM}++$ & $80.29^{\mathrm{Aa}} \pm 4.6$ & $49.0^{\mathrm{Aa}} \pm 1$ & $2.70^{\mathrm{Ab}} \pm .76$ & $273^{\mathrm{Aa}} \pm 31$ \\
\hline \multicolumn{6}{|c|}{ Significant of Source of variation $\quad(\mathrm{ns}=$ not significant, $* \mathrm{P} \leq 0.05, * * \mathrm{P} \leq 0.01, * * * \mathrm{P} \leq 0.001)$} \\
\hline \multicolumn{2}{|c|}{ Mycorrhizae (M) } & $* *$ & Ns & ns & ns \\
\hline \multicolumn{2}{|c|}{ Water Supply (WS) } & $* * *$ & $* * *$ & $* * *$ & $* * *$ \\
\hline \multicolumn{2}{|c|}{$\mathrm{M} * \mathrm{WS}$} & $* * *$ & $* * *$ & $* * *$ & ns \\
\hline
\end{tabular}

Despite differences between treatments within the same water supply regime, but total carotenoids and lycopene concentrations were decreased as much as water supply was increased. In Control plants, total carotene decreased by 22 and $31 \%$ in both $\mathrm{WS}_{50}$ and $\mathrm{WS}_{100}$ compared to $\mathrm{WS}_{0}$, and similar losses was observed for lycopene. Decreases in both total carotene and lycopene contents a long water supply increase were even more in $\mathrm{AM}+$ and $\mathrm{AM}++($ Table 3). Remarkable increase in $\beta$-Carotene content was measured in $\mathrm{AM}++$ fruits under both $\mathrm{WS}_{0}$ and $\mathrm{W}_{100}$ but not under $\mathrm{WS}_{50}$. Fruits contained more ascorbic acid only in unirrigated $\mathrm{WS}_{0}$ plants, while a slight improve was found in AM++ in half water supply without reaching significant levels (Table 3).

The soluble solid content ( ${ }^{\circ}$ Brix) showed a strong adverse relationship with the yield.plants with no water supply $\mathrm{WS}_{0}$ were able to support only about $20 \%$ of the potential yield, thus the highest ${ }^{\circ}$ Brix was obtained about 8 , regardless of mycorrhizal inoculation. Under both $\mathrm{WS}_{50}$ and $\mathrm{WS}_{100}$, a reduction of one unit of ${ }^{\circ}$ Brix was observed in the range of 50 to $100 \mathrm{t} \mathrm{ha}^{-1}$ of marketable fruit. Although the concentration of soluble solids decreased, yield increase compensated ${ }^{\circ}$ Brix loses as a result of the mass quantity of the soluble solids per area $\left(\mathrm{t} \mathrm{h}^{-1}\right)$. Soluble solid production illustrated a strong positive linear correlation with the marketable yield (Fig. 2). 


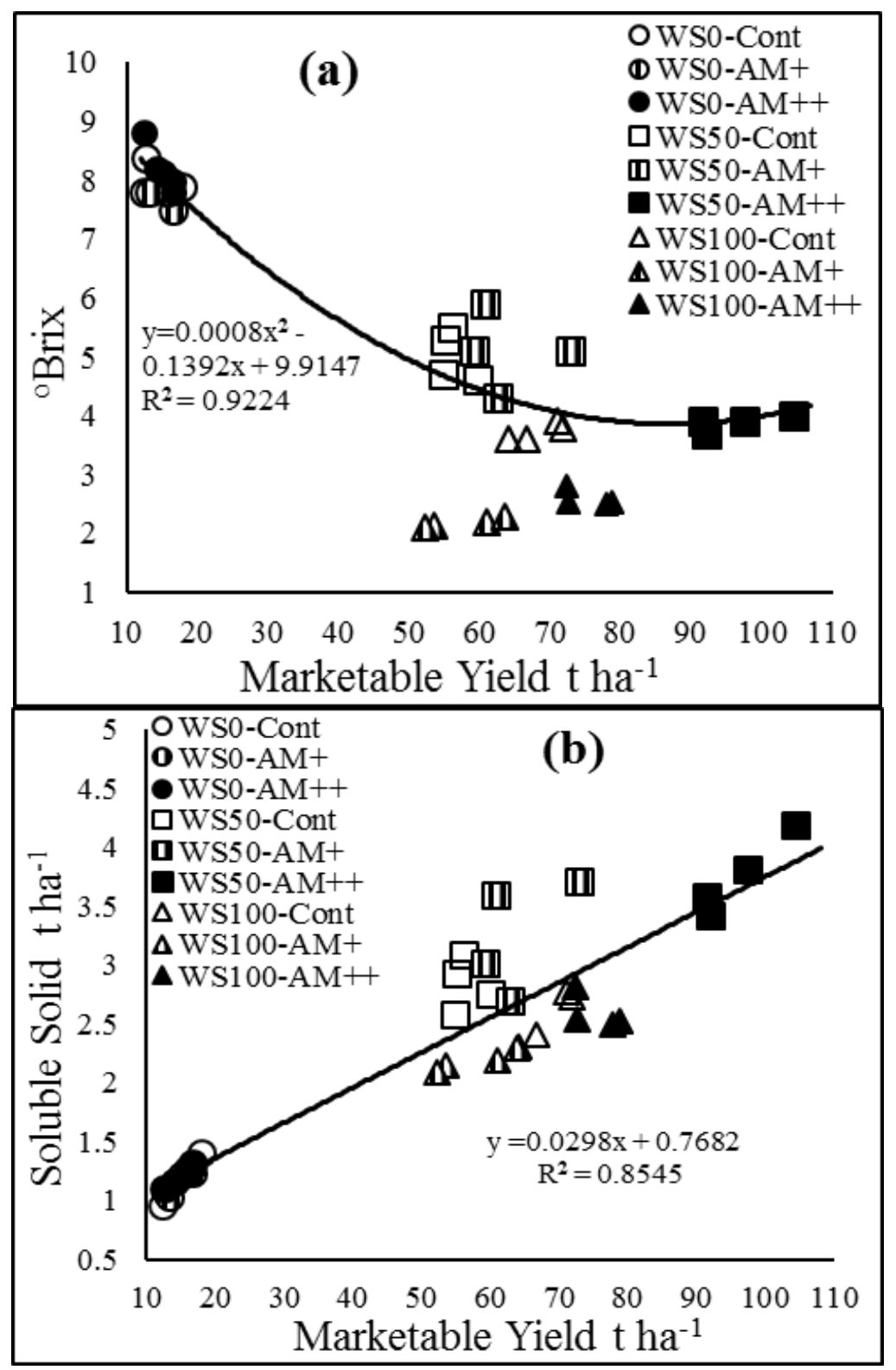

Figure 2. Yield impact on (a) soluble solid ( ${ }^{\circ}$ Brix) content, and (b) soluble solid production.

Along gradients of decreasing water supply, the leaf water potential ( $\psi_{\text {leaf }}$ ) decreased too (the more negative the $\psi$ value, the drier or more water-stressed is the plant), from $(-0.91 \mathrm{MPa})$ in $\mathrm{WS}_{100}$ to $(-1.06 \mathrm{MPa})$ in $\mathrm{WS}_{50}$ and $(-1.55 \mathrm{MPa})$ in $\mathrm{WS}_{0}$ in control plants, while re-inoculated AM++ treatments enhanced and increased the $\psi_{\text {leaf }}$ significantly under all water supply intensities with the best interaction under $\mathrm{WS}_{50}(-0.87 \mathrm{MPa})$. This trend was less pronounced in $\mathrm{AM}+$ treatments. Moreover a strong positive linear correlation $\left(\mathrm{R}^{2}=0.73\right)$ was observed between the $\psi_{\text {leaf }}$ and total biomass (Fig. 3). 


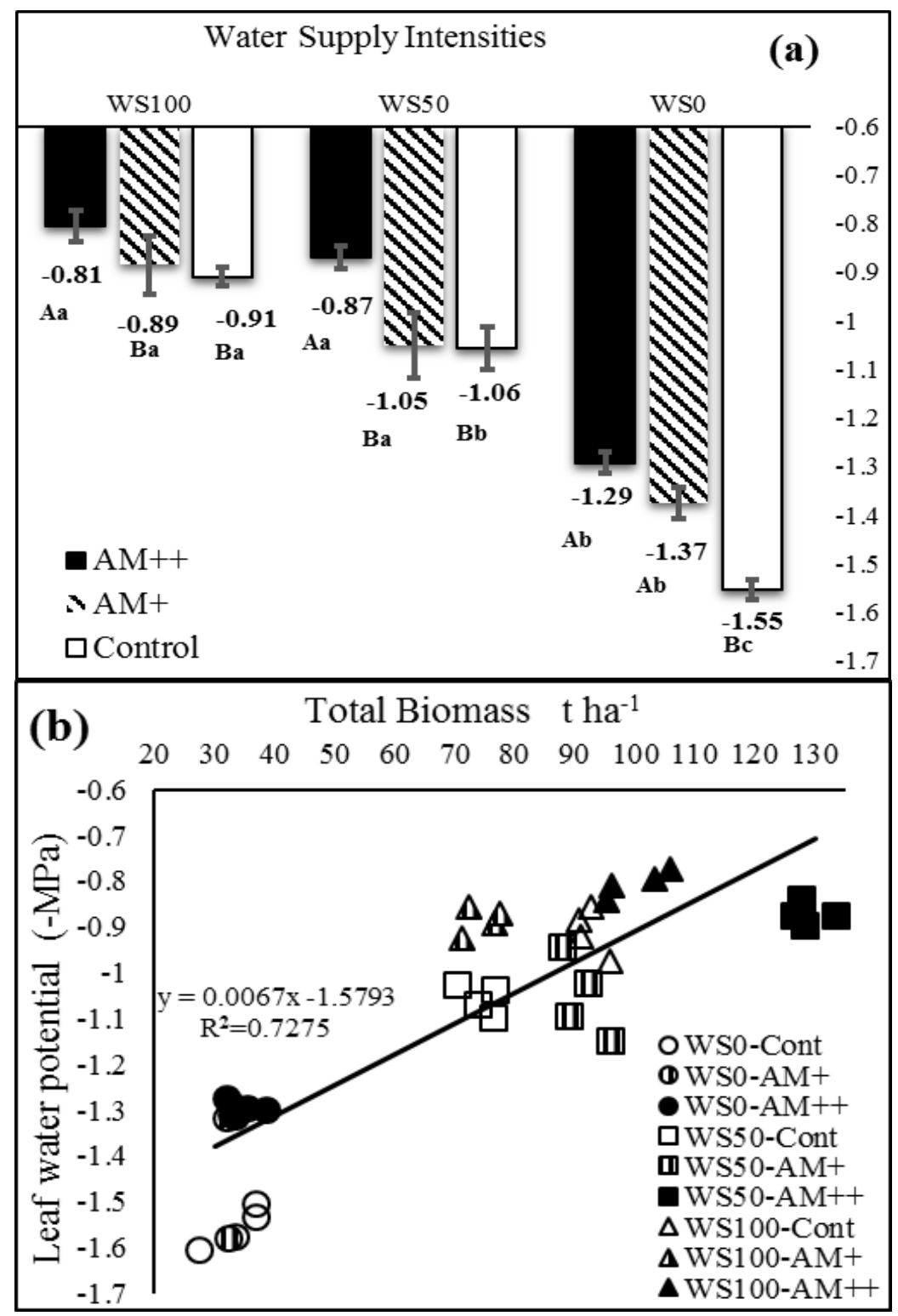

Figure 3. (a) Leaf water potential, (b) Total biomass and leaf water potential relationship. Vertical bars represent standard deviation, capital letters represent mycorrhizal inoculation effect, and small letters represent water supply effect.

\section{Discussion}

Worldwide, field crop production faces water stress that limits crops productivity, and mycorrhizal symbiosis is considered as a key component backing up host plants to overcome water lack stress as it is addressed in numerous of studies (Augé, 2001; Smith and Read, 2008; Ruiz-Sanchez et al., 2010; Candido et al., 2015). In this field-based trial, mycorrhizal re-inoculation, boosted yield, and enhanced growth and water use efficiency under both half- and full-water supply regimes compared to non-inoculated and at sowing inoculated plants as it was also found by others (Di Cesare et al., 2012).

Despite, the relatively high colonization rate by the endogenous mycorrhizal fungi, control tomato plants showed no enhancement neither in growth nor physiologically compared to inoculated plants (Table 1). This may related to mycorrhizal effectivity, 
which affects by the genotype combinations of host plant and the mycorrhizae, and the fact of functional differences of AMF: different fungal species are different in their effectiveness to enhance plant water uptake from the soil, as it was reviewed from several previous studies (Baum et al., 2015). Regardless of water supply levels, both inoculation at sowing and re-inoculation with the commercial Symbivit significantly increased the rate of root colonization, moreover the colonization rate was not affected by water stress (Table 1), which also found in previous studies as summarized by Augé (2001). Thus resulted in higher total biomass under half water supply condition and this was in agreement with other reports that additional mycorrhizal inoculations can improve growth, and colonization of field crops (Lekberg et al., 2005; Ortas et al., 2013).

The great increase in water use efficiency in inoculated plants compared to noninoculated under half water supply (Table 1) is a definite prove, that mycorrhizal inoculation increased the ability of the root to increase water uptake from the soil (Ruth et al., 2011). Enhancing the water use efficiency by AM inoculation was also found in sweet pepper (Jezdinsky et al., 2012), and in tomato (Bowles et al., 2016). Moreover the higher leaf water potential in inoculated plants (Fig. 3) also supports this assumption.

Leaf water potential is the most important index of plant water status showing its potential to resist drought through better water uptake or better hydration. We recorded higher (less negative) leaf water potential in mycorrhizae colonized plants under half water supply (Fig. 3), supporting a study, illustrated higher leaf water potential in host plants colonized by arbuscular mycorrhizae fungi (Porcel and Ruiz-Lozano, 2004), and contradicting many previous studies surveyed by Augé (2001).

Volumetric soil water content has been in rage of $0.11-0.14$ corresponding to $37-52 \%$ of the field capacity throughout the growing season, resulted in partial soil drying in half water supply zone. Moreover the enhancement in growth, and water use efficiency due mycorrhizal inoculation was more pronounced under half water supply, providing field-based evidence that AMF was more effective under moderate dried soil conditions in half water supply compared to both severe dried soil in none irrigated and optimum soil moisture conditions under full water supply. More effective phosphorus absorption by mycorrhized roots from dry soil was also evidenced by Neumann and George (2005) in a compartmented pot system.

In this field trial, AM re-inoculation was the most potential in enhancing marketable fruit yield in $\mathrm{WS}_{50}$, with increases of about $71 \%$ compared to non-inoculated, and about $51 \%$ compared to inoculation at sowing (Table 2), exceeding that obtained by Candido et al. (2015), who used a single inoculum G. mosseae GP11, and recorded an increase of about $11 \%$, and also the $25 \%$ yield increase by Bowles et at. (2016) under field conditions.

In general $\mathrm{WS}_{0}$ fruits contained relatively higher antioxidants and ascorbic acid concentrations compared to $\mathrm{WS}_{50}$ and $\mathrm{WS}_{100}$ (Table 3); this could be because of the cooler period (Fig. 1) at the end of July prior to the harvest, since the rain-fed tomatoes were harvested two weeks earlier compared to $\mathrm{WS}_{\mathbf{5 0}}$ - and $\mathrm{WS}_{\mathbf{1 0 0}}$-tomatoes and this is in agreement with the explanation of Dumas et al. (2003), and the fact that abiotic factors such as temperature, light, and water supply affect natural antioxidants composition in tomatoes (Pék, et al., 2014) or in plants in general (Hasanuzzaman et al., 2012).

During the ripening stage high temperature affected lycopene formation negatively, this also affected the total carotenoids, since lycopene forms most of carotenoids. No changes in total carotene, lycopene, $\beta$-Carotene and ascorbic acid contents were found in full water supply due to mycorrhization, expect a slight loos for lycopene in AM++, 
while higher total carotene, lycopene, and $\beta$-Carotene levels was observed in AM+ fruits under half water supply (Table 3). This increase in antioxidant compound in fruit of mycorrhized plants could be due to enhanced growth and nutrient acquisition (Ulrichs et al., 2008), but we could not meet both high yield accompanied with high nutrient content.

\section{Conclusion}

Results of this experiment support field-based evidence that arbuscular mycorrhizae fungal inoculation with the commercial product Symbivit can be an integrated application of processing tomato production alleviating water deficit stress as well as improving processing tomato cultivation by increasing its yield with respect to the quality. AM reinoculation at transplanting is more effective than inoculation at sowing only, but economical aspect should be considered, since more inoculum is required. Under actual agroecosystem conditions many biological and environmental factors are interacting, therefore optimizing AM fungi application is required to reach promising results.

Acknowledgments. Thanks to Stipendium Hungaricum, Research Centre of Excellence 14764/2016/FEKUT, and GINOP-2.2.1-15-2016-00003.

\section{REFERENCES}

[1] Augé, R.M. (2001): Water relations, drought and vesicular-arbuscular mycorrhiza symbiosis. -Mycorrhiza 11: 3-42.

[2] Barrios-Masias, F.H. and Jackson, L.E. (2014): California processing tomatoes: Morphological, physiological and phenological traits associated with crop improvement during the last 80 years. - European Journal of Agronomy 53, 45-55.

[3] Baum, C., El-Tohamy, W., Gruda, N. (2015): Increasing the productivity and product quality of vegetable crops using arbuscular mycorrhizal fungi. - Scientia Hoticulturae 187: 131-141.

[4] Bowles, T.M. , Barrios-Masias, F.H., Carlisle, E.A., Cavagnaro, T.R., Jackson, L.E. (2016): Effects of arbuscular mycorrhizae on tomato yield, nutrient uptake, water relations, and soil carbon dynamics under deficit irrigation in field conditions. - Science of the Total Environment 566-567:1223-34. doi: 10.1016/j.scitotenv.2016.05.178.

[5] Candido, V., Campanelli, G., D'Addabbo, T., Castronuovo, D., Perniola, M., Camele, I. (2015): Growth and yield promoting effect of artificial mycorrhization on field tomato at different irrigation regimes. - Scientia Horticulturae 187: 35-43.

[6] Daei, G., Ardekani, M., Rejali, F., Teimuri, S., Miransari, M. (2009): Alleviation of salinity stress on wheat yield, yield components, and nutrient uptake using arbuscular mycorrhizal fungi under field conditions. - Journal of Plant Physiology 166:217-225.

[7] Daood, H.G., Biacs, P.A., Dakar, M.A., Hajdu, F. (1994): Ion-pair chromatography and photodiode-array detection of vitamin $\mathrm{C}$ and organic acids. - Journal of Chromatographic Science 32(11): 481-487.

[8] Daood, H.G., Bencze, G., Palotas, G., Pek, Z., Sidikov, A., Helyes, L. (2014): HPLC Analysis of carotenoids from tomatoes using cross-linked C18 column and MS detection. - Journal of Chromatographic Science 52(9): 985-991.

[9] Di Cesare, L.F., Migliori, C., Ferrari, V., Parisi, M., Campanelli, G., Candido, V., Perrone, D. (2012): Effects of irrigation-fertilization and irrigation mycorrhization on the alimentary and nutraceutical properties of tomatoes. In: Lee, T.S. (Ed.), Irrigation 
Systems and Practices in Challenging Environments. InTech, Rijeka (Croatia), pp. 207232.

[10] Dumas, Y., Dadomo, M., Lucca, G. Di., Grolier, P. (2003): Effects of environmental factors and agricultural techniques on antioxidant content of tomatoes. - Journal of the Science of Food and Agriculture 83:369- 382.

[11] Endresz, G., Mojsez, A., Kalapos, T. (2015): Deficit watering reduces plant growth to a smaller extent with arbuscula mzcorrhizal association than without it for non-invasive grass species but not for invasive grass species. - Applied Ecology and Environmental Research 13(2): 551-567.

[12] Farooq, M., Wahid, A., Kobayashi, N., Fujita, D., Basra, S.M.A. (2009): Plant drought stress: effects, mechanisms and management. - Agronomy of Sustainable Development 29:185-212.

[13] Francis, F.J. (2002): Food colorings. - In: D.B. Mac Dougall (ed.), Colour in Food: Improving Quality. Woodhead Publishing Ltd., Cambridge.

[14] Giovannetti, M. and Mosse, B. (1980): Evaluation of the techniques for measuring vesicular arbuscular mycorrhizal infections in roots. - New Phytologist 84: 489-500.

[15] Hasanuzzaman, M., Hossain, M.A., Silva, J.A.T., Fujita, M. (2012): Plant response and tolerance to abiotic oxidative stress: antioxidant defense is a key factor. - In: Venkateswarlu B, Shanker AK, Shanker C, Maheswari M (eds) Crop stress and its management: perspectives and strategies. Springer, Berlin.

[16] Helyes, L. and Varga, G. (1994): Irrigation demand of tomato according to the results of three decades. - Acta Horticulturae 367:323-328.

[17] Helyes, L., Lugasi, A., Brandt, S., Varga, Gy., Hóvári, J., Barna, É. (2002): Evaluation and analysis of factors affecting lycopene content of tomato (A paradicsom likopin tartalmát befolyásoló tényezők értékelése, elemzése). - Kertgazdaság 34:1-8.

[18] Helyes, L., Lugasi, A., Pék, Z. (2006): Tomato fruit quality and content depend on stage of maturity. - HortScience 41:1400-1401.

[19] Jezdinsky, A., Vojtiskova, J., Slezak, K., Petrikova, K., Pokluda, R. (2012): Effect of drought stress and Glomus inoculation on selected physiological processes of sweet pepper (Capsicum annuum L. cv 'Slavy'). - Acta Universitatis Agriculturae Et Silviculturae Mendelianae Brunensis 60: 69-76.

[20] Johnstone, P.R., Hartz, T.K., LeStrange, M., Nunez, J.J., \& Miyao, E. M. (2005): Managing fruit soluble solids with late-season deficit irrigation in drip-irrigated processing tomato production. HortScience, 40(6), 1857-1861.

[21] Lekberg, Y. and Koide, R.T. (2005): Is plant performance limited by abundance of arbuscular mycorrhizal fungi? A meta-analysis of studies published between 1988 and 2003. - New Phytologist 168:189-204.

[22] Lopez, J., Riuz, R.M., Ballestores, R., Circuleos, A., Ortiz, R. (2001): Color and lycopene content of several commercial tomato varieties at different harvesting dates. - Acta. Hort. 542: 243-247.

[23] Magurno, F., Sasvari, Z., Posta, K. (2015): Assessment of native arbuscular mycorrhizal fungi assemblages under different regimes of crop rotation. - Applied Ecology and Environmental Research 13(4): 1215-1299.

[24] Neumann, E., and George, E. (2004): Colonisation with the arbuscular mycorrhizal fungus Glomus mosseae (Nicol. \& Gerd.) enhanced phosphorus uptake from dry soil in Sorghum bicolor (L.). - Plant Cell Environ. 261:245-255.

[25] Ordookhani, K., Khavazi, K., Moezzi, A., \& Rejali, F. (2010): Influence of PGPR and AMF on antioxidant activity, lycopene and potassium contents in tomato. African Journal of Agricultural Research 5(10): 1108-1116.

[26] Ortas, I., Sari, N., Akpinar, C., Yetisir, H. (2013): Selection of arbuscular mycorrhizal fungi species for tomato seedling growth, mycorrhizal dependency and nutrient uptake. European Journal of Horticultural Science 78(5): 209-218. 
[27] Patanè, C., Tringali, S., Sortino, O. (2011): Effects of deficit irrigation on biomass, yield, water productivity and fruit quality of processing tomato under semi-arid mediterranean climate conditions. - Scientia Horticulturae 129 (4): 590-596.

[28] Pék, Z., Helyes, L., Lugasi, A. (2010): Color changes and antioxidant content of vine and post-harvest ripened tomato fruits. - HortScience 45:466-468.

[29] Pék, Z., Szuvandzsiev, P., Daood, H., Neményi, A., Helyes, L. (2014): Effect of irrigation on yield parameters and antioxidant profiles of processing cherry tomato. - Open Life Science 9(4):383-395.

[30] Phillips, J.M. and Hayman, D.S. (1970): Improved procedures for clearing roots and staining parasitic and vesicular-arbuscular mycorrhizal fungi for rapid assessment of infection. - Transactions of the British Mycological Society 55: 158-161.

[31] Planchette, C., Fortin, J.A., Furlan, V. (1983): Growth response of several plant species to mycorrhiza in a soil of moderate fertility. I. Mycorrhizal dependency under field conditions. - Plant and Soil 70:199-209.

[32] Porcel, R., and Ruiz-Lozano, J.M. (2004): Arbuscular mycorhhizal influence on leaf water potential, solute accumulation and oxidative stress in soybean plants subjected to drought stress. - J. Exp. Bot. 55:1743-1750.

[33] Rana, G., Rinaldi, M., Introna, M., Ciciretti, L. (2000): Determinazione sperimentale dei consumi idrici del pomodoro da industria in Capitanata. - Atti Convegno Pom B19. Salerno, Italy, 6 Nov. 6: 99-106. (in Italian)

[34] Ruiz-Sánchez, M., Aroca, R., Muñoz, Y., Armada, E., Polón, R., Ruiz-Lozano, J.M. (2010): The arbuscular mycorrhizal symbiosis enhances the photosynthetic efficiency and the antioxidative response of rice plants subjected to drought stress. - Journal of Plant Physiology 167:862-869.

[35] Ruth, B., Khalvati, M., Schmidhalter, U. (2011): Quantification of mycorrhizal water uptake via high-resolution on-line water content sensors. - Plant and Soil 342: 459-468.

[36] Smith, S.E. and Read, D.J. (2008): Mycorrhizal symbiosis, 3rd edition. Academic Press, London.

[37] Ulrichs, C., Fischer, G., Büttner, C., Mewis, I. (2008): Comparison of lycopene, bcarotene and phenolic contents of tomato using environmental and horticultural practices, and arbuscular mycorrhizal fungi (AMF). - Agronomia Colombiana 26(1):40-46.

[38] WPTC (2016): World Production estimates of tomatoes for processing as of March 06, 2016. World processing tomato Council at http://www.wptc.to/pdf/releases (site accessed Mar.30, 2016).

[39] Zhang, Y., Yao, Q., Li, J., Hu, Y.L., Chen, J.Z. (2014): Growth response and nutrient uptake of Eriobotrya japonica plants inoculated with three isolates of arbuscular mycorrhizal fungi under water stress condition. - Journal of Plant Nutrition 37: 690-703. 